\title{
Effects of Ficus syncomorus and Datura metel stem-bark extracts on the sperm
} characteristics of Yankasa rams

*Okpara, J. O., *Abudul, M. B., *Garba, S. I., "Adelowo, O. V. and **Mbgojikwe, A. C. ${ }^{*}$ Federal College of Animal Health and Production Technology,

N.V.R.I. Vom, Nigeria.

**Federal College of Forestry Technology, Jos, Nigeria.

Corresponding author: jokpara2015@gmail.com; 08053153651

\section{Abstract}

Interest in medicinal plants for the management of myriad of conditions including reproductive disorders refractory to orthodox medicinal care is on the increase. Ficus syncomorus and Datura metel are two of such plants with folkloric evidence of aiding fertility in human. This study investigated the effect of aqueous stem-bark extracts (200 $m g / k g)$ of F. syncomorus and D. metel respectively on the sperm characteristics of Yankasa rams. Twelve (12) matured (15 - 16 months) old rams were used in this study and randomly assigned into three (I, II, III) groups of four (4) animals each. Group I served as the control while II and III served as the treatment groups and received daily oral doses $(200 \mathrm{mg} / \mathrm{kg})$ of F. syncomorus and D. metel extracts respectively for 7 consecutive days. Semen was collected from all the groups at the end of the treatments using Electro-ejaculation method and evaluated by light microscopy. The mean semen volume (68.70+4.2 to $65.62 \pm 2.00)$ and percentage progressive motile cells significantly $(p<0.05)$ reduced 7 days post treatment in

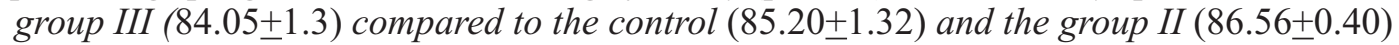
animals. The mean sperm count, the percentage liveability and the haematological parameters and erythrocytic indices $(10.81 \pm 0.24$ for group 111 to $12.54 \pm 0.30$ for group 1$)$ significantly $(p<0.05)$ decreased in group III compared to the values in the control and group II rams. Abnormal sperm morphology (bent mid-piece, curved tail, headless tail, tailless head) significantly $(p<0.05)$ increased in D. metel group $(7.26 \pm 0.12)$ compared to $F$.

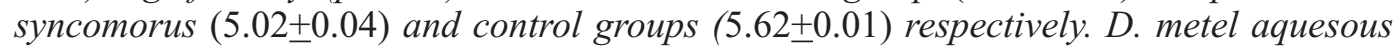
extract adversely affected sperm characteristics with significant effect on semen volume, sperm morphology and counts as well as haematological parameters. Exposure of animals to $D$. metel at the dose used may impair sperm fertilizing ability, thus leading to reduced ram fertility. While F. syncomorus extract appears a potential drug candidate for improving fertility.

Keywords: Ficus syncomorus, Datura metel, sperm characteristics, morphology, Yankasa rams.

\section{Introduction}

There has been a geometric growth in the attractiveness of medicinal plants in many part of the world because of their acceptance as true innocuous and believe that what is natural can only be good (Okpara, 2015). The floral biodiversity of Africa provides the African traditional medical practitioners with an impressive "natural pharmacy" from which plants are selected as remedies, and ingredients to prepare herbal medicines for an array of human and animal diseases (Oyewole, 2003; 2004). Although in Nigeria, there are no professional traditional veterinary practitioners as such some herdsmen, village elders and others who kept animals have acquired experiences for generations in diagnosing and treating animal disease conditions. Sometimes the same herbs used in treating human diseases are also used in treating corresponding animal diseases 
(Nwude, 1997; Okpara, 2006). However, there are some herbs that are used mainly for veterinary purposes and some diseases peculiar to animals (Nwude, 1997, Okpara et al., 2018). It has been observed that in the tropical environment, animals reared under extension husbandry systems thrive better and are usually able to withstand some of the endemic diseases to which intensively managed animals continually remain susceptible (Huffman, 2001). This apparent disease resistance has been attributed in part, to adequate exercise and the possibility of selective and unrestricted grazing whereby a wide variety of edible forages are available to animals; some of these plants have been shown to provide not only nutrition but are also of medicinal benefits (Adedapo et al., 2002; Okpara, 2015). A growing body of evidence has shown the phenomenon of self -medication in animals (Huffman, 2002).

A variety of non-nutritional compounds from plants are found in the diet of animals, but little is known about the possible medicinal consequences of their ingestion. One of the challenges of interpreting selfmedication in animals is to distinguish between indirect medical benefits derived from plants rich in secondary compound that are assumed to be ingested for their nutritional value versus limited and situation specific ingestion of items that are processed solely for their curative value or other physiological effects (Cousin and Huffman, 2002). Ficus syncomarus and Datura metel are employed in folkloric medicine to improve libido as well as to withstand stress (Okpara et al., 2018). In Nigeria, the Hausas' referred to D. metel as zakami or Hankata yaro while $F$. synccomorus, is the wild fig in English and known as Bature in hausa language. The health, growth and productive performance of animals especially livestock are affected by the chemical composition of the plants they consume (Nwude, 1997). To distinguish edible from poisonous plants, grazing animals were observed and plants not eaten were considered poisonous and were avoided by man. Thus, plants are generally studied either for their medicinal or toxicological effects. This study is aimed at evaluating the effects of Ficus syncomarus and Datura metel aqueous extract in the sperm characteristic of Yankasa rams.

\section{Materials and methods Studyarea}

The study was carried out at the small ruminant section of the teaching and research farm of the Federal College of Animal Health and Production Technology, N.V.R.I., Vom, Plateau state.

\section{Animals, treatment and management}

Twelve 15 to 16 months old Yankasa rams of 12 to $13 \mathrm{~kg}$ were used for the study in a completely randomised design. Before the experiment, the animals were washed with Taktic Amitraz ${ }^{R}$ (Intermet International, the Netherland) to rid them of ectoparasites and dewormed with albendazole solution (25mglkg). The rams were fed with $350 \mathrm{~g}$ concentrates supplemented with rice hay and maize silage and water was provided $a d$ Iibitum throughout the period of the experiment. The fed concentrate comprised of maize $(40 \mathrm{~kg})$, soybeans meal $(5.5 \mathrm{~kg})$, groundnut cake $(200 \mathrm{~g})$, wheat offal $25 \mathrm{~g}$, bone meal $(2 \mathrm{~g})$, premix $(0.5 \mathrm{~g})$ and salt $0.5 \mathrm{~g}$. The rams were randomly allotted into three (3) groups (I, II and III) of four (4) animals each. Group I was the control and Groups II and III rams were administered with $200 \mathrm{mglkg}$ of $F$. syncomorus and D. metel aqueous extracts respectively per $0 S$ daily for seven (7) consecutive days. Seven (7) days post treatment blood and semen samples were collected and analysed for possible changes in haematological parameters and sperm characteristics. 


\section{Haematological analysis}

Five $(5 \mathrm{ml})$ millilitres of blood were collected from each ram via the jugular vein into anticoagulant (EDTA) containing bottles 7 days post treatment. The blood samples were analysed using automated electronic cell counter (Abbort Haematological Analyser, Cell - Dyn, 1700, IIIinois, USA) for absolute and differential white blood cell count (WBC), erythrocytes count (RBC), packed cell volume (PCV), and haemoglobin $(\mathrm{Hb})$ concentration. The erythrocytic indices (MCV, MCH, MCHCH) were calculated using the methods described by Schalm et al. (1975)

Mean corpuscular volume (MCV)MCV $(\mathrm{fL})=\underline{\mathrm{PCVX}} 10$ $\operatorname{RBC}(1012 / \mathrm{L})$

MCV expresses the average volume of the individual erythrocytes

Mean corpuscular Haemoglobin (MCH)

$\mathrm{MCH}(\mathrm{Pg})=\underline{\mathrm{Hb}(\mathrm{g} / \mathrm{dL}) \mathrm{X} 10}$

$\operatorname{RBC}(10$ 12/L)

Mean corpuscular Haemoglobin concentration (MCHC)

$\operatorname{MCHC}(\mathrm{g} / \mathrm{dL})=\underline{\mathrm{Hb}(\mathrm{g} / \mathrm{dL}) X 100}$ $\mathrm{PCV}(\%)$

Semen collection - (Electro ejaculation method) and evaluation

The electro - ejaculator consist of a wooden rectal probe and metal electrode with a total length of $12.0 \mathrm{~m}$ and a diameter of $1.5 \mathrm{~cm}$ (body) and $1.0 \mathrm{~cm}$ at the tip connected to a transformer to control delivered current at $18 \mathrm{~Hz}$ with output voltage of $\mathrm{O}-12 \mathrm{~V}$. The probe was lubricated with paraffin oil before insertion into the rectum to minimize trauma. It is inserted $8-10 \mathrm{~cm}$ into the rectum and the electrode positioned vertically. The probe was inserted such that the electrode was within the pelvic cavity. The anal sphincter was also lubricated to minimise trauma. The animals were held in a standing position during the semen collection exercise and the entire procedure lasts for approximately 2 minutes. The electricity stimulation was for interval of 4 - 5 seconds. Ejaculate from each animal was collected with a beaker and the ejaculate volume, excluding the gel read off immediately in measuring cylinder and recorded, the semen was further evaluated Zaneveld and Polakoshi, (1977). A drop of undiluted semen from each animal was placed on a clean, pre - warmed $\left(37^{\circ o}\right)$ glass slide and examined with microscope under low power to determine the mass activity of spermatozoa for each animal. The scoring was according to the intensity of the wave motion from absence of wave motion to very turbulent motion $(+++)$, characterised by the appearance of dark prominent waves in a very rapid motion. The semen progressive motility was evaluated as described by Kastelic et al. (2001). The percentage live sperm as determined by counting live/dead sperm in a thin smear of a drop of semen mixed with eosin-negrosin stain (Hancook, 1952). Spermatozoa slide were also evaluated for morphological abnormalities (Maimgram and Larssun, 1984), consisting of primary defects (those affecting the head) and secondary defects (those affecting the midpiece or tail). The respective aqueous stem-bark extracts of $F$. Syncomorus and D. metel were kept in airtight container in cool and dry place until use.

Collection, preparation and extraction of $F$ syncomorus and $D$. metel aqueous extracts

The stem-bark of the plants (F. syncomorus and $D$. metel) were collected from apparently healthy plants within the premises of National Veterinary Research Institute (NVRI), Vom, Plateau State, Nigeria. The stem-barks were air dried for 21 days and ground in a Hammer mill. Samples of the dried $F$. syncomorus and $D$. metel stem-barks powder were analysed for proximate and chemical composition 
(AOAC, 1990). The cations ( $\mathrm{Ca}, \mathrm{Mg}, \mathrm{Cu})$ in the sample were estimated using atomic absorption spectrophotometer with warelength: $\mathrm{Mg}=286.4 \mathrm{~nm} ; \mathrm{Ca}=422.8 \mathrm{~nm}$, $\mathrm{Cu}=325.7 \mathrm{~nm}$.

In extracting the plants stem-bark powder, five hundred grams $(500 \mathrm{~g})$ each of the plant materials were mixed in a container in $2.5 \mathrm{~L}$ of distilled water and stirred. After $24 \mathrm{hrs}$ the contents were filtered coarsely using clean cotton wool and subsequently with whatmann No. 1 filter paper. The filtrates were heated to dryness in hot air oven at $40^{\circ}$ to obtain the solid extract (Sofowora, 1993).

\section{Phytochemical analysis}

This was carried out as described by Sofowora (1993) and Hammuet et al. (2014). For tannins (FeCl test); about $0.5 \mathrm{~g}$ of the dried powdered extracts (for $F$. syncomorus and D. metel) were dissolved in $20 \mathrm{~mL}$ of distilled water in a test tube, boiled and filtered; to each filtrate few drops of $1.0 \%$ Iron II chloride solution were added and observed for a blue green precipitate. Flavonoids test; this was conducted in two different ways. To $1.0 \mathrm{~mL}$ of the extract 1.0 $\mathrm{mL}$ of $10 \%$ lead acetate was added, and observed for yellowish precipitation. Also, to $1.0 \mathrm{~mL}$ of the extracts $1.0 \mathrm{~mL}$ of dilute $\mathrm{NaOH}$ was added and observed for precipitation. Alkaloids Test: For this two different reagents (Wagners and Mayers reagents) were used to ascertain the presence of alkaloids in the sample. To $2 \mathrm{~mL}$ of the extract was added $10.0 \mathrm{~mL}$ of $2 \% \mathrm{HCl}$ mixed thoroughly by shaking and emerged on a steam bath and filtered. Thereafter, the filtrates were divided into two equal portions. To the first portion Wagner's reagent was added in drops and observed for a brown precipitate. To the second portion of the filtrate Mayer's reagent was added also in drops and observed for white to yellow or creamy white precipitate. Saponnins test (Frothing test): One (1.0)
$\mathrm{mL}$ of the extract was boiled in $5 \mathrm{ml}$ of distilled water for 5 minutes and decanted while still hot. Further, it was filtered and $1.0 \mathrm{~mL}$ of the filtrate was diluted with $4.0 \mathrm{ml}$ of distilled water and was shook vigorously. It was observed on standing for stable froth. Glycosides test ( $\mathrm{FeCl}$ test); to $5.0 \mathrm{~mL}$ of the extract in a test tube $2.5 \mathrm{~mL}$ of dilute $\mathrm{H}_{2} \mathrm{SO}_{4}$ acid was added and boiled in a water bath for 15 minutes. It was cooled and neutralized with $20 \% \mathrm{KOH}$ solution, then $5 \mathrm{ml}$ of a mixture of Fehling's solution A and $\mathrm{B}$ were added and observed for reddish brown colour at the interphase. Cardiac glycosides test; To $1.0 \mathrm{~mL}$ of the extract $80 \%$ of methanol was added and mixed with $1.0 \mathrm{~mL}$ of $2 \%$ solution of 3,5 dinitrobenzoic acid in $95 \%$ alcohol. The solution was made alkaline with $5 \% \mathrm{NaOH}$. It was observed for violet colour which faded through reddish brown to brownish yellow. Carbohydrate test; (Molish test). The extract $(0.5 \mathrm{~g})$ was dissolved in $3 \mathrm{ml}$ of distilled water, heated for 5 minutes in a hot water bath. It was filtered and allowed to cool. Five drops of Molish reagent was added to the solution and gently shaken. Furthermore, concentrated $\mathrm{H}_{2} \mathrm{SO}_{4}$ of $0.5 \mathrm{~mL}$ was added carefully from the side of the test tube. The presence of reddish coloured interfaced ring indicated the presence of carbohydrate in the extract (Harborne, 1998). Test for Steroids (Salkowaki test): One millitres $(1 \mathrm{~mL})$ of the extract was treated with 5 drops of concentrated H2S04. The presence red colouration indicates the presence of steroids.

\section{Statistical analysis}

Data obtained from the experiment were analysed using the statistical analysis of variance (ANOVA) procedure of SAS (2010) and significant level of $p=0.05$ was used. The treatment means were compared using the Tukey's HSD option of the same software. 


\section{Okpara, Abudul, Garba, Adelowo and Mbgojikwe}

\section{Results}

The results of phytochemical constituent of aqueous stem-bark extracts of $\underline{F}$. syncomorus and D. metel in Table 1 shows that tannins, flavonoids, alkaloids and carbohydrates were present in the stem bark extracts of both $\underline{F}$. syncomorus and $D$. metel while saponins was absent in $\underline{F}$. syncomorus but present in D. metel. Glycosides and cardiac glycosides were absent in $\underline{F}$. syncomorus but present in $D$. metel while steroids were observed to be absent in both $\underline{F}$. syncomorus and D. metel. Table 2 shows the effect of $\underline{F}$. syncomorus and $D$. metel stem-bark on aqueous extracts $(200 \mathrm{mg} / \mathrm{kg})$ on the erythrocytic parameters and indices of Yankasa rams. The erythrocytic parameters and indices were all significantly different $(\mathrm{p}<0.05)$ from the control, the red blood cells $\left(\mathrm{X} 10^{2} / \mathrm{L}\right)$ increasingly ranges from $10.81 \pm 0.24$ for $D$. metel to $12.54 \pm 0.30$ in the control while $F$. syncomorus value is $12.64 \pm 0.56$. The haemoglobin $(\mathrm{g} / \mathrm{dL})$ values ranges from $9.54 \pm 0.30$ in $D$. metel to $11.30 \pm 0.47$ in $F$. Syncomorus, the PCV (\%) values ranges significantly $(\mathrm{p}<0.05)$ from $25.42 \pm 0.45$ in $D$. metel to $29.78 \pm 0.81$ in F. Syncomorus. The MCV (FL) values also varies significantly from $22.75 \pm 0.10$ in $D$. metel to $24.73 \pm 0.42$ in F. Syncomorus while the $\mathrm{MCH}(\mathrm{pg})$ and $\mathrm{MCHC}(\mathrm{g} / \mathrm{dL})$ values were all significantly different across the treatments with values of $F$. Syncomorus highest compared with $D$. metel with lowest values in all the parameters measured. The results in Table 3 shows effects of $F$. Syncomorus and D. metel aqueous extracts $(200 \mathrm{mg} / \mathrm{kg})$ on the total and differential Leucocyte counts. The WBC $\left(\mathrm{X} 10^{9} / \mathrm{L}\right)$ also increase significantly $(\mathrm{p}<0.05)$ with D.metel having the lowest value of $23.04 \pm 0.77$ while $F$. syncomorus had the highest value of $25.30 \pm 0.97$, the Neutrophil $\left(\mathrm{X} 10^{9} / \mathrm{L}\right)$ values also varies significantly $(\mathrm{p}<0.05)$ with $D$. metel was also observed to have the lowest value of $11.84+0.19$ but the control with $13.54 \pm 0.84$. The Lymphocyte $\left(\mathrm{X} 10^{9} / \mathrm{L}\right)$ values also increase significantly and range from $8.05 \pm 0.75$ to $10.22 \pm 0.86$ respectively, the Eosinophil $\left(\mathrm{X} 10^{9} / \mathrm{L}\right)$ ranges from $0.64 \pm 0.10$ in D.metel to $1.02 \pm 0.07$ in $F$. syncomorus. The Monocyte $\left(\overline{\mathrm{X}} 10^{9} / \mathrm{L}\right)$ also varies significantly $(\mathrm{p}<0.05)$ and ranges from $0.54 \pm 0.40$ to $0.75 \pm 0.10$ while Basophil $(1 \overline{0} / \mathrm{L})$ ranges significantly from $0.20 \pm 0.07$ to $0.44 \pm 0.08$. The result in Table 4 revealed semen characteristics of rams administered (200mg/kg) of F. syncomorus and $D$. metel extracts. The control $(68.70 \pm 4.2)$ was observed to have the highest volume of semen compared to D.metel $(65.62 \pm 2.00)$ and F. syncomorus (67.92 \pm 2.04$)$. Mass activity was uniform across the treatments while progressive motility was in $F$. syncomorus $(86.56 \pm 0.40)$, followed by the control $(85.20 \pm 1.32)$ while D.metel $(84.05 \pm 1.3)$ had the lowest motility. The sperm concentration was not significantly different across the treatments. The percentage of life sperm/dead was highest in $F$. syncomorus $(78.62 \pm 1.02)$ with D.metel $(74.50 \pm 1.25)$ having the lowest value, the total sperm ejaculate was highest in group 11 and lowest in group 111. The morphological abnormalities were highest in group $111(7.26 \pm 0.12)$ and lowest in group $11(5.02 \pm 0.04)$.

\section{Discussion}

The phytochemical screening of Ficus syncomorus and Datura metel stem-bark extracts revealed the presence of flavonoids, alkaloids, tannins, saponnins and glycosides. Steroids was present in $D$. metel only. This agrees with previous work of Okpara et al. (2018) who observed the presence of these secondary plant metabolites in $F$. syncomorus and D. metel leaves obtained at Vyang District, Jos South 
Effects of Ficus syncomorus and Datura metel stem-bark extracts on the sperm characteristics

Table 1: Phytochemical constitutes of aqueous stem-bark extracts of $\boldsymbol{F}$. syncomorus and D. metel

\begin{tabular}{lll}
\hline Constituents & F. syncomorus & D. metel \\
\hline Tannins & + & + \\
Saponins & - & + \\
Flavonoids & + & + \\
Alkaloids & + & + \\
Glycosides & - & + \\
Cardiac glycosides & - & + \\
Steroids & - & - \\
Carbohydrates & + & + \\
\hline
\end{tabular}

Key: +=Present -=Absent

Table 2: Effects of $F$. syncomorus and D. metel stem-bark. aqueous extracts (200mg/kg) on the erythrocytic parameters and indices of Yankasa rams

\begin{tabular}{llll}
\hline Parameter/Indices & Control & F. syncomorus & D. metel \\
\hline $\mathrm{RBC}\left(\mathrm{X} 10^{2} / \mathrm{L}\right)$ & $12.54+0.30^{a}$ & $12.64+0.56^{a}$ & $10.81+0.24^{b}$ \\
$\mathrm{Hb}(\mathrm{g} / \mathrm{dL})$ & $10.84 \pm 0.12^{a}$ & $11.30 \pm 0.47^{a}$ & $9.54 \pm 0.30^{b}$ \\
$\mathrm{PCV}(\%)$ & $28.67 \pm 0.19^{a}$ & $29.78 \pm 0.81^{a}$ & $25.42 \pm 0.45^{b}$ \\
MCV (FL) & $23.62 \pm 0.14^{a}$ & $24.73 \pm 0.42^{a}$ & $22.75 \pm 0.10^{b}$ \\
MCH (pg) & $8.74 \pm 0.08^{a}$ & $9.04 \pm 0.21^{a}$ & $7.03 \pm 0.36^{b}$ \\
MCHC (g/dL) & $37.56+32^{a}$ & $38.06+0.14^{a}$ & $36.13+0.18^{b}$ \\
\hline
\end{tabular}

abc means on the same row with different superscripts are significantly different $(\mathrm{p}<0.05)$

$\mathrm{rbc}=$ red blood corpuscles, $\mathrm{hb}=$ heamoglobin, $\mathrm{pcv}=$ packed cell volume, $\mathrm{mch}=$ mean corpuscular

haemoglobin, $\mathrm{mcv}=$ mean corpuscular volume, $\mathrm{mchc}=$ mean corpuscular haemoglobin concentration

Table 3: Effects of F. Syncomorus and D. metel aqueous extracts $(200 \mathrm{mg} / \mathrm{kg})$ on the total and differential leucocyte counts $(n=3)$

\begin{tabular}{llll}
\hline Parameter & Control & F. syncomorus & D. Metel \\
\hline WBC $\left(\mathrm{X} 10^{9} / \mathrm{L}\right)$ & $24.88 \pm 1.20^{\mathrm{a}}$ & $25.30 \pm 0.97^{\mathrm{a}}$ & $23.04 \pm 0.77^{\mathrm{b}}$ \\
Neutrophil $\left(\mathrm{X} 10^{9} / \mathrm{L}\right)$ & $13.54 \pm 0.84^{\mathrm{a}}$ & $13.43 \pm 0.75^{\mathrm{a}}$ & $11.84 \pm 0.19^{\mathrm{b}}$ \\
Lymphocyte $\left(\mathrm{X} 10^{9} / \mathrm{L}\right)$ & $9.82 \pm 0.51^{\mathrm{a}}$ & $10.22 \pm 0.86^{\mathrm{a}}$ & $8.05 \pm 0.75^{\mathrm{b}}$ \\
Eosinophil $\left(\mathrm{X} 10^{9} / \mathrm{L}\right)$ & $0.95 \pm 0.10^{\mathrm{a}}$ & $1.02 \pm 0.07^{\mathrm{a}}$ & $0.64 \pm 0.10^{\mathrm{b}}$ \\
Monocyte $\left(\mathrm{X} 10^{9} / \mathrm{L}\right)$ & $0.70 \pm 0.35^{\mathrm{a}}$ & $0.75 \pm 0.10^{\mathrm{a}}$ & $0.54 \pm 0.40^{\mathrm{b}}$ \\
Basophil $\left(10^{9} / \mathrm{L}\right)$ & $0.40 \pm 0.05^{\mathrm{a}}$ & $0.44 \pm 0.08^{\mathrm{a}}$ & $0.20 \pm 0.07^{\mathrm{b}}$ \\
\hline \multicolumn{2}{l}{ abcMeans on the same row with different superscripts are significantly different $(\mathrm{p}<0.05)$}
\end{tabular}

Table 4: Semen characteristics of rams administered $(200 \mathrm{mg} / \mathrm{kg})$ of $F$. syncomorus and D. metel. extracts

\begin{tabular}{|c|c|c|c|}
\hline Parameter & Control & F. syncomorus & D. Metel \\
\hline Volume of semen & $68.70+4.2^{\mathrm{a}}$ & $67.92 \pm 2.04^{\mathrm{a}}$ & $65.62+2.00^{\mathrm{b}}$ \\
\hline Mass activity & +++ & +++ & +++ \\
\hline Progressive motility & $85.20 \pm 1.32^{\mathrm{b}}$ & $86.56 \pm 0.40^{\mathrm{a}}$ & $84.05 \pm 1.3^{\mathrm{b}}$ \\
\hline Sperm concentration & $0.43+3.01^{\mathrm{a}}$ & $0.43+0.02^{\mathrm{a}}$ & $0.43+0.02^{\mathrm{a}}$ \\
\hline Life sperm/dead (\%) & $75.2 \overline{7} \pm 1.35^{\mathrm{b}}$ & $78.62 \pm 1.02^{\mathrm{b}}$ & $74.50 \pm 1.25^{\mathrm{a}}$ \\
\hline Total sperm/Ejaculate & $27.50 \pm 1.35^{\mathrm{b}}$ & $28.25 \pm 1.03^{\mathrm{a}}$ & $26.74 \pm 0.08^{\mathrm{b}}$ \\
\hline $\begin{array}{l}\text { Morphological } \\
\text { abnormalities }\end{array}$ & $5.62+0.01^{\mathrm{a}}$ & $5.02 \pm \mathrm{a} 0.04^{\mathrm{a}}$ & $7.26 \pm 0.12^{\mathrm{b}}$ \\
\hline
\end{tabular}




\section{Okpara, Abudul, Garba, Adelowo and Mbgojikwe}

L.G.A, Plateau State, Nigeria. Secondary plant metabolites exact a number of biological activities such as antibacterial, anti-inflammatory, antidiarrheal, antioxidant, antiageonic, analgesic and antiallergic properties (Okpara, 2015). Tannins have been found to react with proline rich protein to form irreversible complexes (Umeh et al., 2011), resulting in the inhibition of cell protein synthesis. Tannins rich herbs are astringents in nature and are used for treating gastro-intestinal disorders such as diarrhoea and dysentery (Oyewole, 2003; 2004). The presence of flavonoids and saponnins in these plants lend credence to their uses in managing inflammation and stress related conditions. The decrease in RBC, PCV, HB as well as in the erythrocytic indices $(\mathrm{MCV}, \mathrm{MCH}$ and $\mathrm{MCHC}$ ) in the D. metel treated group compared to the control and the $F$. syncomorus groups could be attributed to the possible toxic effect of the extract (Ambali et al., 2011). The RBC is susceptible to lipo peroxidative changes because of its direct association with molecular oxygen, high content of metal ions catalysing oxidative reactions and availability of high amount of polyunsaturated fatty acids (PUFA's) which are susceptible to lipid peroxidation. The decrease in the erythrocyte parameters and indices in the $D$. metel group could also be attributed to possible disruption of haemopoisis due to intracellular oxidative stress. Haemoglobin biosynthesis takes place in the mitochondria and toxic inhibition of the activities of enzymes such as alpha-aminolevulinic acid synthase (ALA-synthase) and prophobilinogen synthase will affect the $\mathrm{Hb}$ synthetic pathway (Okpara, 2015). The disruption of the activities of any of these enzymes due to oxidative damage to macromolecules may interfere with haemoglobin production, thus defective and decreased erythrocyte production. Therefore, the decrease in (MCV, $\mathrm{MCH}$ and $\mathrm{MCHC}$ ) values in the $D$. metel treated groups could also be attributed to the disruption in haeme biosynthetic pathway, hence in haemopois leading to the production of microcytes. The significant increase in both the erythrocytic parameters and indices in the F. syncomorus group showed that the extract contains phytochemical(s) with antioxidant and enzyme enhancing properties. Furthermore, the reduction in total WBC count in $D$. metel treated group could be attributed to lymphopenia and or neutropenia resulting from possible release of superoxide and other free radicals which, are toxic to cells including neutrophils and lymphocytes thereby causing a decrease in their peripheral circulation (Okpara, 2015). The elevation in the haematological parameters in the F. syncomorus group is speculated to be due to chain breaking antioxidant activity of one of the phytochemicals flavonoids present in the extract or combined effects of various phytochemicals (Okpara et al., 2018). This played a vital role in the maintenance of cellular membrane integrity as well as stimulating the immune system (Ebaid et al., 2013). Datura metel stem-bark aqueous extract showed a significant decrease in sperm volume and adverse effects on spermatogenesis as manifested in an increase in the number of headless tail sperm cells compared to the values obtained for the control and $F$. syncomorus group. The headless tail abnormalities according to Bloom (1948) and Oladele et al. (2010) is primarily caused as a result of disruption in the course of spermatogenesis which may be due to the generation of reactive species by the toxic extract (Ada and Egbunike, 2010). The decrease in the number of headless, tailless head and bent tail sperm cells observed in the $F$. syncomorus treated group showed that the extract has protective 


\section{Effects of Ficus syncomorus and Datura metel stem-bark extracts on the sperm characteristics}

effect on the sperm cells (Malmgan and Larsson, Kastelic etal; 2001). The results of the present study further lend credence to the social and medical uses of these plants in many parts of Nigeria.

\section{References}

Adedeji, T. A., Ojedapo, L. O., Ojebiyi, O. O., Olayeni, T. B. and Akinwumi, A. O. 2006. Small holder herd structure of West African Dwarf goats in a derived savannah environment area of Nigeria. Nigeria Journal of Animal Production, $33(1,2)$ : 245 - 253.

Asaolu, V. O. and Odeyinka, S. M. 2006. Performance of WAD sheep fedcassava peel based diets. Nigeria Journal of Animal Production, 23 $(1,2): 230-238$.

Ambali, S. F., Shittu, M., Ayo, J. O., Esievo, K. A. and Ojo, S. A. 2011. Vitamin C, alleviated chromic chlorpyrifos-induced alterations in serum lipids and oxidative parameters in male Wistar rats. American Journal of Pharmacology and Toxicology, 6 (4): $100-118$.

Ada, O. A. and Egbunike, G. N. 2010. Sperm quality, fertility and reproductive organs weight of pubertal boars fed dietary copper. Journal of Applied Agricultural Research, 2: 61-74.

Bloom, E. 1948. On methods of evaluating bull sperm. Dyrlaegeforenning, 31:446.

Cousin, D and Huffman, M. A. 2002. Medicinal properties in the diet of gorillas. An ethnoveterinary evaluation. African study Monogrph 23 (2): 65-89.

Ebaid, H., Bashandy, S. A. E., Alhazza, I. M., Rady, A. and Shehry, S. 2013. Folic acid and $\mathrm{m}$ e 1 a t o $\mathrm{n}$ i n ameliorates carbon tetrachlorideinduced hepatic injury, oxidative stress and inflammation in rats. Nutrition and Metabolism, 10 (20): $101-120$.

FAO 1992. Food and Agricultural Organisation Production Year Book; 1992 Rome Italy.

Hancock, J. L. 1951. Procedures for preparation, cokedies, evoluotries and insemination of $\quad \mathrm{b}$ o $\mathrm{r} \mathrm{n}$ e semen. Journal of Experimented Biology, 29: 445 - 448.

Harborne, J. B. 1998. Phytochemical methods. Takenham Press Ltd, Worthfolk, $250 \mathrm{p}$.

Huffman, M. A. 2001. Self-Medicative behaviour in African greatapes. An evolutionary $\mathrm{perceptive}$ into the origin of human traditional medicine. Biosciences, 5 (8): 1 11.

Kastelic, S. P., Cook, R. B., Person, R. A. and Coulter, G. H. 2001. Relationship among scrotal and testicular characteristics, sperm production and semi quality in 129 beef bulls. Canadian Journal of Veterinary Research, 65: $111-115$.

Malmgran, L. and Larsson, K. 1984. Semen quality and fertility after heat stress in boars. A C T A Veterinaria scandinaries, 25: $425-$ 435.

Nwude, N. 1997. Ethno-veterinary pharmacology and ethnoveterinary practices in Nigeria. An Overview. Tropical Veterinarian, 15:117-123

Oladele, G. M. and Abatan, M. O. 2010. Haematological and sperm count changes following exposure to hyptis suaveolens, cleome viscosa and urena lobata in rats. Phytomedicine, 2:340-370. 
Oyewole, J.A. O. 2003. Evaluation of antiinflammatory propertices of Sclerocarya birrea (Anacardiacad stem - bark extracts in rats. Journal of Ethnopharmacology, 85:217 220.

Oyewole, J. A. O. 2004. Evaluation analgesic, anti-inflammatory and anti-diabetic properties of Sclerocarya birrea. Phytotherapy Research, 18:601-608.

Okpara, J. O., Atiku, A. A., Salihu, A. A., Kaigama, G. J. and Mojbojikee, A. C. 2018. Haematological and biochemical changes induced by carbon tetrachloride in Wistar rats: Amelioative effects of Carica papaya (Pawpaw) leaf aqueous extract. International Journal of science and Applied Research (IJSAR), (1)i 1 - 19.

Okpara, J. O. 2015. Evaluation of safety, antioxidant and antidirrhoeal activities of the flavonvid fraction of Dichrostachys glomerates leaves. Ph.D Veterinary Pharmacology Thesis; Ahmadu Bello University, Zaria, Nigeria, 288 pp.
SAS 2010. SAS/STAT User's Guide: Version 9.2. SAS Institute Inc., Cary. NC., USA, 2010. Schalm, O. W., Jain, W. C and Carol, E. S. 1975. Veterinary Haematology, $3^{\text {rd }}$ Edition Lea and Ferbinger, Philadephia, Pg. 20-28.

Umeh, S. O., Okonkwo, I. F. and Chufusi, J. N. 2011. Phytochemical screening, antimicrobial and antidiarrhoeal activities of the leaf extract of sweet broom (Scoparia dulcis. International Journal of Agriculture and Biosciences, 1(1): 1-4

Zaneveld, L. J. D and Polakoski, K. L. 1977. Collection and physical examination of the ejaculate in: Techniques of human andrology (ed. ESE, 1+afez), e/Seviea Amsterdam, the Netherlands.

Received: $10^{\text {th }}$ October, 2019 Accepted: $17^{\text {th }}$ February, 2020 